\title{
Improved Dust Detection over East Asia Using Geostationary Satellite Data
}

\author{
Yu-Rim Shin $^{1} \cdot$ Eun-Ha Sohn ${ }^{2} \cdot$ Ki-Hong Park $^{1} \cdot$ Geun-Hyeok Ryu ${ }^{1} \cdot$ Soobong Lee ${ }^{1} \cdot$ Seon-Young Lee ${ }^{1}$. Na-Yeon Park ${ }^{1}$
}

Received: 24 July 2020 / Revised: 30 October 2020 / Accepted: 20 December 2020 / Published online: 26 February 2021

(C) The Author(s) 2021

\begin{abstract}
This paper presents an improved algorithm, based on the $\mathrm{D}^{*}$-parameter, for dust detection over the East Asian region using brightness temperature differences (BTDs) between the infrared channels of the Advanced Himawari Imager (AHI) onboard Himawari-8. The developed algorithm defines a dust index in the form of the ratio of BTDs: BTD between the $10.4 \mu \mathrm{m}$ and $12.4 \mu \mathrm{m}$ channels $\left(\mathrm{BTD}_{10.4-12.4}\right)$ to that between the $8.6 \mu \mathrm{m}$ and $10.4 \mu \mathrm{m}$ channels $\left(\mathrm{BTD}_{8.6-10.4}\right)$. To identify dust with this index, threshold values were determined empirically. A masking technique using the $\mathrm{BTD}_{8.6-10.4}$ was utilized in the dust index to mitigate the problem of detecting clear-sky deserts and fog over the ocean as dust. $\mathrm{BTD}_{8.6-10.4}$ was analyzed for dust, clear-sky desert, and fog over the ocean cases during 2017 and 2018 with this method. Fog over the ocean and clear-sky desert were distinguished by the criteria of $\mathrm{BTD}_{8.6-10.4}>-1.1 \mathrm{~K}$ and $\mathrm{BTD}_{8.6-10.4}>-1 \mathrm{~K}$, respectively. Based on these thresholds, the influence of fog over the ocean and clear-sky desert was filtered out. The results showed that the dust area was qualitatively consistent with RGB images and ground observation data. Comparison with the AERONET aerosol optical depth (AOD) demonstrated that the $\mathrm{D}^{*}$-parameter was exponentially proportional to $\mathrm{AOD}$, and the correlation coefficient between them was approximately 0.6. The improved Asian Dust detection algorithm can be applied to the monitoring of dust dispersion and movement and also serve as a quantitative indicator of Asian Dust.
\end{abstract}

Keywords Asian dust $\cdot$ Dust detection algorithm $\cdot$ Himawari- $8 \cdot$ Infrared channel $\cdot$ BTD

\section{Introduction}

Asian Dust occurs over large regions of East Asia, especially during spring. Every year, the Asian Dust event occurs for approximately 6-7 days on average over the Korean Peninsula. It mainly originates from the Gobi desert and Inner Mongolia and is often transported through the Bohai bay or Manchuria (NIMS 2019). As the dust travels to Japan with the westerlies, the dust height rises to approximately 1.5

Responsible Editor: Yun Gon Lee.

Na-Yeon Park

nayeonpark@korea.kr

1 Satellite Analysis Division, National Meteorological Satellite Center, Korea Meteorological Administration, 64-18 Guam-gil,

Gwanghyewon-myeon, Jincheon-gun, Chungcheongbuk-do 27803, South Korea

2 Numerical Data Application Division, Numerical Modeling Center, Korea Meteorological Administration, 61 16-gil, Yeouidaebang-ro, Dongjak-gu, Seoul 07062, South Korea
$3 \mathrm{~km}$ under various conditions, such as cold fronts with strong winds, baroclinic instability, a reinforcement of the pressure gradient, and influences from Northeast Asia (Guo et al. 2017).

Dust directly or indirectly changes the atmospheric radiation balance and cloud characteristics through scattering and absorption (Haywood and Boucher 2000; Wurzler et al. 2000), affecting weather, air quality, hydrological circulation, and ecosystems. Therefore, continuous monitoring of the outbreak and movement of dust is required. The physicochemical properties of dust can be determined by observation from ground-based observatories, but it is difficult to track its movement and distribution. Dust detection using satellite data with a wide viewing range is essential, and geostationary orbital satellite observation with a high temporal resolution is more effective in monitoring dust in real-time.

Various studies on dust detection have been conducted using visible and infrared spectral regions. Among them, remote sensing techniques using thermal measurements from satellites are advantageous in that they facilitate dust detection during nighttime and over high-albedo surfaces (Ackerman 
1997). The optical properties of dust at infrared wavelengths are related to the spectral refractive index of combined minerals and the particle size distribution (Sokolik and Toon 1999).

Various dust detection methods using infrared channels have been developed based on the optical characteristics of minerals. Shenk and Curran (1974) studied dust outbreaks originating from the Sahara Desert using a single channel $(10.5-12 \mu \mathrm{m})$ of the Nimbus-4 satellite for the first time. Legrand et al. (1989) mentioned the possibility of estimating dust optical depth using a single channel $(10.5-12.5 \mu \mathrm{m})$ of METEOSAT-2. As techniques that use a single channel are sensitive to surface emissivity and changing atmospheric conditions (Ackerman 1997; Liu et al. 2013), the brightness temperature difference (BTD) between two infrared channels has been used to distinguish the surface, clouds, and aerosols (Schneider et al. 1995; Zhang et al. 2006; Schepanski et al. 2007). Aerosol detection using BTD was first attempted by Prata (1989), using the difference in the absorption coefficients of the $11 \mu \mathrm{m}$ and $12 \mu \mathrm{m}$ channels. The emissivity of $\mathrm{SiO}_{2}$, which is the main component of dust, has a minimum value in the 8.0-9.7- $\mu \mathrm{m}$ wavelength range and a maximum value in the $12-13-\mu \mathrm{m}$ wavelength range, showing an increase with wavelength (Vickers and Lyon 1967). With these characteristics, $\mathrm{BTD}_{11-12}$ over dust is negative because aerosol absorption is stronger at $11 \mu \mathrm{m}$ than $12 \mu \mathrm{m}$, and $\mathrm{BTD}_{11-12}$ over clouds is positive due to stronger absorption at $12 \mu \mathrm{m}$ (Prata 1989; Yamanouchi et al. 1987; Sokolik 2002; Gu et al. 2003). However, the $\mathrm{BTD}_{11-12}$ method is strongly affected by the surface temperature along with emissivity, the satellite zenith angle, and the vertical profile of water vapor (Ha et al. 2006).

To reduce the false detection caused by these factors and increase accuracy, dust indexes, such as the Infrared Difference Dust Index (IDDI), the Kosa (Yellow sand) monitoring product, the Infrared Optical Depth Index (IODI), the Aerosol Index (AI), and the $\mathrm{D}^{*}$-parameter $\left(\mathrm{D}^{*}\right)$ were introduced by adding channels or using various techniques. Legrand et al. (2001) proposed the IDDI, derived from the difference between brightness temperature (TB) assuming clear weather conditions and the observed TB obtained from the Meteosat 10.5-12.5 $\mu \mathrm{m}$ channel; however, the dust storm intensity was distorted where the emissivity was high (Kim et al. 2008). Hashimoto and Ohkawara (2007) defined the Kosa monitoring product using an equation based on the ratio over the $11 \mu \mathrm{m}$ and $12 \mu \mathrm{m}$ channels of the Multi-Functional Transport Satellite (MTSAT)-1R satellite data. Yet, deposited dust to the surface or dispersed dust was difficult to detect. Kim et al. (2008) developed the IODI, the physical meaning of which corresponds to dust intensity; this index uses the difference in optical depth for infrared wavelengths under clear-sky and dust-laden conditions. However, dust under clouds was, at times, incorrectly detected with a low detection accuracy for water droplets and ice crystals (El-Askary et al. 2015). Hong et al.
(2010) introduced a new concept called Brightness Threshold Value (BTV), using the brightness temperature of clear sky based on MTSAT-1R satellite data to remove factors affecting $\mathrm{BTD}_{11-}$ ${ }_{12}$, and developed the aerosol index (AI) dust detection method. The Korea Meteorological Administration (KMA) of the National Meteorological Satellite Center (NMSC) applied the AI dust detection method using Communication, Ocean, and Meteorological Satellite (COMS) data. Applying the AI to these data, the BTV was masked for cases including clouds throughout the observation period, and high positive BTV values were computed in many cases over oceans that have a large amount of water vapor. This caused false dust signals over clear sky or weak dust signals when correcting the BTD error. Accordingly, the $8.6 \mu \mathrm{m}$ channel, which has a large spectroscopic variability for quartz particles and a greater water absorption than the $11 \mu \mathrm{m}$ and $12 \mu \mathrm{m}$ channels (Ackerman 1997), was added to overcome this problem. Most signals for the three channels $(8.6 \mu \mathrm{m}$, $11 \mu \mathrm{m}$, and $12 \mu \mathrm{m})$ in the infrared window range come from the surface (Tang and Li 2008), and the brightness temperature of these three infrared window channels is used to effectively detect dust because the dust layer is mostly located in the lower troposphere.

In this study, as a method using the three infrared channels, $D^{*}$ was applied to the Himawari-8 geostationary satellite. D* was developed by Hansell et al. (2007) using the Moderate Resolution Imaging Spectroradiometer (MODIS) imager of low earth orbit satellites. The Himawari-8 satellite has a high temporal resolution and enables continuous monitoring, unlike MODIS. However, similar to the case of the AI, previous application results revealed problems of incorrectly detecting fog over the ocean and perceiving clear-sky desert surfaces as dust due to the impact of the sign of $\mathrm{BTD}_{10.4-12.4}$, corresponding to the numerator of the $\mathrm{D}^{*}$ equation. The characteristics of $\mathrm{BTD}_{8.6-10.4}$ according to meteorological phenomena were detected to directly eliminate the effects of clear-sky desert and fog over the ocean.

The objectives of this research were to propose the $\mathrm{D}^{*}$ parameter index based on geostationary satellite observation and optimize it for the East Asia region. The remainder of this paper is structured as follows. Section 2 describes the used data, Section 3 presents the dust detection algorithm and its improvement methods. The improved $\mathrm{D}^{*}$ performance is demonstrated for selected cases in Section 4, and Section 5 finally concludes the paper with a summary and discussion.

\section{Data}

\subsection{Himawari-8 Satellite Infrared Data}

Himawari-8 was launched on 7 October 2014 by the Japan Meteorological Agency (JMA) and has been in operation since 7 July 2015. The advanced sensor of Himawari-8, AHI (Advanced Himawari Imager), is similar to the ABI sensor of 
the GEOS-R satellite. Its resolution and number of channels have been significantly improved compared to previous geostationary satellites, such as MTSAT-1R and MTSAT-2. The AHI can retrieve and improve various products by observing the radiation with 16 channels and can perform a more detailed analysis with a spatial resolution of $0.5-2 \mathrm{~km}$ and a temporal resolution of $10 \mathrm{~min}$ (Table 1 ). In this study, Himawari-8 channels $11(8.6 \mu \mathrm{m}), 13(10.4 \mu \mathrm{m})$, and 15 $(12.4 \mu \mathrm{m})$ were selected as wavelengths, similar to MODIS infrared bands $29(8.6 \mu \mathrm{m}), 31(11 \mu \mathrm{m})$, and $32(12 \mu \mathrm{m})$, which were used in Hansell et al. (2007). These wavelengths were used by converting their level $1 \mathrm{~B}$ data in $2 \mathrm{~km}$ resolution to TB. In addition, a land/sea mask was used to improve the false detection for deserts under clear-sky and fog over the ocean. The study was conducted with 4 cases of dust events in spring and winter in 2017 and 2018, focusing on the East Asia region, including the origin areas of Mongolia and China (latitude of approximately $10.2^{\circ} \mathrm{N}-60.7^{\circ} \mathrm{N}$ and longitude of approximately $78.3^{\circ} \mathrm{E}-175.7^{\circ} \mathrm{E}$ ).

\subsection{Data for Evaluation of Dust Detection Method}

To evaluate the performance of the improved dust detection algorithm during the day, true color RGB images from the Geostationary Ocean Color Imager (GOCI) loaded on COMS and AHI mounted on the Himawari- 8 satellite were used. The result was also compared with AI images retrieved from the Meteorological Imager (MI) loaded on COMS.
For the nighttime, when visible channels are not available, the following data were used: infrared channel-based Himawari-8 dust RGB image and $\mathrm{PM}_{10}$ concentration chart. The $\mathrm{PM}_{10}$ concentration chart was provided by the KMA and based on data observed through the air quality monitoring network in mainland China. A comparison of the results with COMS AI and Himawari-8 D* was also carried out. COMS AI uses infrared channels $10.8 \mu \mathrm{m}$ and $12 \mu \mathrm{m}$, and its output was utilized to support weather forecast until recently. In this study, the COMS AI was used to compare the performance of $\mathrm{D}^{*}$.

RGB images are composites of red, green, and blue colors for various channel combinations based on the characteristics of channels according to the observation purpose. These images can provide more information of the surface and atmosphere than single-channel images. True color RGB images are produced by synthesizing three visible channels, having large spectral response functions for red, green, and blue, respectively. True color RGB images provide color information similar to human vision and can distinguish dust, haze, and clouds. The red, green, and blue of the true color RGB of the GOCI correspond to $0.68 \mu \mathrm{m}, 0.555 \mu \mathrm{m}$, and $0.412 \mu \mathrm{m}$, and those of the AHI correspond to $0.64 \mu \mathrm{m}$, a blend between $0.51 \mu \mathrm{m}$ and $0.86 \mu \mathrm{m}$, and $0.46 \mu \mathrm{m}$, respectively. The dust RGB image comprises a combination of $\mathrm{BTD}_{12.4-10.4}$, $\mathrm{BTD}_{10.4-8.6}$, and $\mathrm{BTD}_{10.4-13.3}$ corresponding to red, green, and blue, respectively. This dust RGB image enables the differentiation of not only dust, but also clouds and surface information (Table 2).

Table 1 Comparison of the specifications of MTSAT-2/IMAGER and Himawari-8/AHI

\begin{tabular}{|c|c|c|c|c|c|c|c|}
\hline \multicolumn{4}{|c|}{ MTSAT-2/IMAGER } & \multicolumn{4}{|c|}{ Himawari-8/AHI } \\
\hline $\begin{array}{l}\text { Channel } \\
\text { name }\end{array}$ & $\begin{array}{l}\text { Central } \\
\text { wavelength } \\
(\mu \mathrm{m})\end{array}$ & $\begin{array}{l}\text { Spatial } \\
\text { resolution } \\
(\mathrm{km})\end{array}$ & Interval & $\begin{array}{l}\text { Channel } \\
\text { number }\end{array}$ & $\begin{array}{l}\text { Central } \\
\text { wavelength } \\
(\mu \mathrm{m})\end{array}$ & $\begin{array}{l}\text { Spatial } \\
\text { resolution } \\
(\mathrm{km})\end{array}$ & Interval \\
\hline & & & $\begin{array}{l}\text { Every } 30 \mathrm{~min} \text { for full } \\
\text { disk }\end{array}$ & $\begin{array}{l}1 \\
2\end{array}$ & $\begin{array}{l}0.47 \\
0.51\end{array}$ & $\begin{array}{l}1 \\
1\end{array}$ & $\begin{array}{l}\text { Every } 10 \mathrm{~min} \text { for full disk, } \\
\text { Every } 2.5 \mathrm{~min} \text { for specific }\end{array}$ \\
\hline \multirow[t]{4}{*}{ VIS } & 0.675 & 1 & & 3 & 0.64 & 0.5 & areas \\
\hline & & & & 4 & 0.86 & 1 & \\
\hline & & & & 5 & 1.61 & 2 & \\
\hline & & & & 6 & 2.26 & 2 & \\
\hline IR4 & 3.75 & 4 & & 7 & 3.89 & 2 & \\
\hline \multirow[t]{5}{*}{ IR3 } & 6.75 & 4 & & 8 & 6.24 & 2 & \\
\hline & & & & 9 & 6.94 & 2 & \\
\hline & & & & 10 & 7.35 & 2 & \\
\hline & & & & 11 & 8.59 & 2 & \\
\hline & & & & 12 & 9.64 & 2 & \\
\hline \multirow[t]{2}{*}{ IR1 } & 10.8 & 4 & & 13 & 10.40 & 2 & \\
\hline & & & & 14 & 11.24 & 2 & \\
\hline \multirow[t]{2}{*}{ IR2 } & 12.0 & 4 & & 15 & 12.38 & 2 & \\
\hline & & & & 16 & 13.28 & 2 & \\
\hline
\end{tabular}


The $\mathrm{PM}_{10}$ concentration chart was produced by the National Institute of Meteorological Sciences (NIMS) of the KMA based on $\mathrm{PM}_{10}$ data of China. The $\mathrm{PM}_{10}$ data was provided by the China National Environmental Monitoring Center (CNEMC), which operates an air quality monitoring network covering approximately 1500 stations in China, including the origin and moving routes of Asian dust.

\subsection{AERONET AOD}

AERONET (Aerosol Robotic NETwork (http://aeronet.gsfc.nasa. gov)) is an international observation network for CIMEL (sun/sky spectral radiometer), a sunphotometer observing optical properties of aerosols. The sunphotometer measures the direct solar radiation of 8 spectral bands $(340,380,440,500,675$, $870,940,1020 \mathrm{~nm}$ ) in a $1.2^{\circ}$ full field of view, and has a high spatio-temporal resolution (Holben et al. 1998). AERONET sites provide aerosol optical depths (AOD) at 340, 380, 440, 500, 675, 870 , and $1020 \mathrm{~nm}$ and Ångström exponents between a number of wavelength pairs ( $440-870 \mathrm{~nm}, 380-500 \mathrm{~nm}, 440-675 \mathrm{~nm}, 500$ $870 \mathrm{~nm}$, and $340-440 \mathrm{~nm}$ ) every $15 \mathrm{~min}$ during the daytime (Correia and Pires 2006). The AOD data are obtained from observed radiation using the Beer-Lambert-Bouguer equation and provided in three processing levels: Level 1.0 (unscreened), Level 1.5 (automated cloud screened), and Level 2.0 (assured quality) (Smirnov et al. 2000). AERONET AOD is used as the reference standard for various satellites and model validation because it has a high accuracy of under 0.01 (unitless) for wavelengths longer than $440 \mathrm{~nm}$, and under 0.02 for shorter wavelengths (Eck et al. 1999; Cesnulyte et al. 2013; Giles et al. 2019).
In this study, the level 1.5 AOD data from 28 sites in East Asia, including Korea, China, and Japan were used to verify the practical significance of $\mathrm{D}^{*}$, focusing on dust events in 2017-2018 (Table 3). According to Remer et al. (2005), the $\mathrm{AOD}$ at $550 \mathrm{~nm}$ is more efficient than the AOD retrieved from other wavelengths, although AERONET does not make observations at $550 \mathrm{~nm}$. Therefore, the AOD and Ångström exponent were applied to the Ångström power law relationship to interpolate from $\mathrm{AOD}_{500}$ to $\mathrm{AOD}_{550}$, as shown in eq. (1).

$A O D_{550}=A O D_{500} \times\left(\frac{550}{500}\right)^{-\alpha}$

where $\alpha$ represents the AERONET Ångström exponent of 440$870 \mathrm{~nm}$. The spatial and temporal matching between AERONET $\mathrm{AOD}_{550}$ data and $\mathrm{D}^{*}$ products was performed with an interval of $1 \mathrm{~h}$, according to the period shown in Table 4. Correlation analysis was carried out between the two variables by averaging $\mathrm{D}^{*}$ for a $12 \mathrm{~km}$ radius centered on the closest pixel to the AERONET site, and taking an average of AERONET AOD ${ }_{550}$ within \pm 30 min of satellite data.

\section{Dust Detection Method}

\subsection{D*-Parameter (D*)}

The $\mathrm{D}^{*}$-parameter is a dust detection method proposed by Hansell et al. (2007) and was developed to improve the misidentification of thin cirrus clouds that are often present over dust when using $\mathrm{BTD}_{11-12}$. The $8.6 \mu \mathrm{m}, 10.4 \mu \mathrm{m}$, and
Table 2 Details of configuration channels and interpretation of color for true color RGB and dust RGB images

\begin{tabular}{|c|c|c|c|}
\hline Image type & Instrument & Configuration channels $(\mu \mathrm{m})$ & Interpretation of colors \\
\hline True color RGB & $\begin{array}{l}\text { AHI } \\
\text { GOCI }\end{array}$ & $\begin{array}{l}\text { Red: } 0.64 \\
\text { Green: blend of } 0.51 \text { and } 0.86 \\
\text { Blue: } 0.46 \\
\text { Red: } 0.68 \\
\text { Green: } 0.55 \\
\text { Blue: } 0.41\end{array}$ & $\begin{array}{l}\text { Close to human vision } \\
\text { Dust: tan, ochre, } \\
\text { Haze: gray, } \\
\text { Cloud: white, etc. }\end{array}$ \\
\hline Dust RGB & AHI & $\begin{array}{l}\text { Red: } 12.4-10.4 \\
\text { Green: } 10.4-8.6 \\
\text { Blue: } 10.4-13.3\end{array}$ & $\begin{array}{l}\text { [dust] } \\
\text { Dust: red/magenta/pink } \\
\text { [clouds] } \\
\text { High and thick cirrus: black } \\
\text { Thin cirrus: blue } \\
\text { High opaque clouds: dark red } \\
\text { Mid-level opaque cloud: brown } \\
\text { Mid-level cold, thin cloud: green } \\
\text { Low-level warm cloud: ochre } \\
\text { [surface] } \\
\text { Warm desert: right blue } \\
\text { Cloud desert: reddish blue } \\
\text { Clear surface(land/ocean): blue }\end{array}$ \\
\hline
\end{tabular}


Table 3 Description for latitude, longitude, elevation, and operational information of AERONET sites, from which insitu (ground) validation data were acquired

\begin{tabular}{|c|c|c|c|c|c|}
\hline & Station & Lat. $\left({ }^{\circ} \mathrm{N}\right)$ & Lon. $\left({ }^{\circ} \mathrm{E}\right)$ & Elevation (m) & Operational dates \\
\hline \multirow[t]{8}{*}{ China } & Beijing & 39.9769 & 116.3814 & 92 & Mar 7, 2001-present \\
\hline & Beijing-CAMS & 39.9333 & 116.3167 & 106 & Aug 2, 2012-present \\
\hline & Beijing-PKU & 39.9920 & 116.3102 & 53 & Jun 30, 2016-Oct 30, 2019 \\
\hline & Beijing-RADI & 40.0048 & 116.3786 & 59 & Aug 21, 2007-present \\
\hline & Taihu & 31.4210 & 120.2153 & 20 & Jan 1, 2001-Nov 1, 2018 \\
\hline & XiangHe & 39.7536 & 116.9615 & 36 & Mar 20, 2001-present \\
\hline & XuZhou-CUMT & 34.2167 & 117.1417 & 59.7 & Jun 28, 2013-May 19, 2019 \\
\hline & AOE_Baotou & 40.8517 & 109.6288 & 1314 & May 9, 2003-present \\
\hline \multirow[t]{12}{*}{ Korea } & Anmyon & 36.5385 & 126.3302 & 47 & Sep 25, 1999-present \\
\hline & Ieodo_Station & 32.1230 & 125.1824 & 29 & Nov 30, 2013-Aug 20, 2019 \\
\hline & Socheongcho & 37.4231 & 124.7380 & 28 & Oct 12, 2015-present \\
\hline & Gangneung_WNU & 37.7710 & 128.8670 & 60 & Jun 2, 2012-present \\
\hline & Gwangju_GIST & 35.2283 & 126.8431 & 52 & Feb 3, 2004-Apr 14, 2019 \\
\hline & Hankuk_UFS & 37.3388 & 127.2658 & 167 & Jun 2, 2012-present \\
\hline & $\begin{array}{l}\text { KORUS_Kyungpook_ } \\
\text { NU }\end{array}$ & 35.8900 & 128.6064 & 65 & Mar 2, 2016-Feb 15, 2017 \\
\hline & KORUS_Mokpo_NU & 34.9134 & 126.4374 & 26 & Mar 18, 2016-Feb 11, 2017 \\
\hline & KORUS_UNIST_Ulsan & 35.5819 & 129.1897 & 106 & Feb 3, 2016-Feb 2, 2017 \\
\hline & Pusan_NU & 35.2354 & 129.0825 & 78 & Jun 5, 2012-Feb 14, 2017 \\
\hline & Seoul_SNU & 37.4581 & 126.9511 & 116 & Nov 1, 2000-present \\
\hline & Yonsei_University & 37.5644 & 126.9348 & 97 & Mar 4, 2011-present \\
\hline \multirow[t]{8}{*}{ Japan } & Fukuoka & 33.5240 & 130.4750 & 30 & Sep 19, 2000-present \\
\hline & Fukue & 32.7520 & 128.6820 & 80 & Jun 2, 2012-present \\
\hline & Osaka & 34.6509 & 135.5906 & 50 & Sep 19, 2000-present \\
\hline & Noto & 37.3344 & 137.1369 & 200 & Apr 5, 2001-present \\
\hline & Shirahama & 33.6935 & 135.3569 & 10 & Oct 18, 2000-present \\
\hline & Niigata & 37.8460 & 138.9420 & 10 & Feb 24, 2016-present \\
\hline & Chiba_University & 35.6247 & 140.1038 & 60 & Nov 1, 2011-present \\
\hline & ARIAKE_TOWER & 33.1036 & 130.2720 & 15 & Feb 20, 2018-present \\
\hline
\end{tabular}

$12.4 \mu \mathrm{m}$ channels of the AHI were selected for this study. D* has an exponential form, whose power is the ratio of $\mathrm{BTD}_{10.4}$ 12.4 and $\mathrm{BTD}_{8.6-10.4}$, as shown in Eq. (2).

Table 4 Periods of AERONET data for validation. Himawari-8 D* products at a $1 \mathrm{~h}$ interval, and the AERONET data after \pm 30 min-averaging from the satellite product time was used

Data periods

Apr 16, 2017 - Apr 21, 2017 Jan 15, 2018 - Jan 19, 2018

Apr 29, 2017 - Apr 30, 2017 Feb 8, 2018 - Feb 10, 2018

May 3, 2017 - May, 62,017 Feb 16, 2018 - Feb 17, 2018

May 10, 2017 - May 12, 2017

Nov 15, 2017 - Nov 17, 2017

Nov 27, 2017 - Nov 28, 2017

Dec 28, 2017 - Dec 31, 2017
$D^{*}=\exp \left[\frac{\left(\mathrm{BTD}_{10.4-12.4}\right)-\mathrm{C}}{\left(\mathrm{BTD}_{8.6-10.4}\right)-\mathrm{E}}\right]$

where $\mathrm{C}$ and $\mathrm{E}$ are thermal offsets of $\mathrm{BTD}_{10.4-12.4}$ and $\mathrm{BTD}_{8.6-10.4}$, respectively. The $\mathrm{D}^{*}$ value was found to increase with an increase in $\mathrm{C}$ or a decrease in $\mathrm{E}$. As the power of $\mathrm{D}^{*}$ is the ratio of $\mathrm{BTD}_{10.4-12.4}$ and $\mathrm{BTD}_{8.6-10.4}$, and the numerator and denominators are mutually relative, $\mathrm{C}$ and $\mathrm{E}$ were set to -0.5 and 15, respectively, as in Hansell et al. (2007). Subsequently, the $\mathrm{D}^{*}$ threshold value for dust detection was adjusted empirically. Finally, the dust detection performance was evaluated after noise removal using a moving average filter method, with pixel values in a $3 \times 3$ square. The D* threshold values were seasonally determined to be 0.93 in spring and autumn (March to October) and 0.97 in winter (November to February) (Fig. 1).

Although $\mathrm{D}^{*}$ could discriminate dust mixed with cirrus compared to the use of $\mathrm{BTD}_{10.4-12.4}$ only, some issues still 


\section{Himawari-8 / AHI dataset}

- TB 8.6, TB 10.4 and TB $12.4(2 \mathrm{~km} \times 2 \mathrm{~km})$

- Landsea Mask

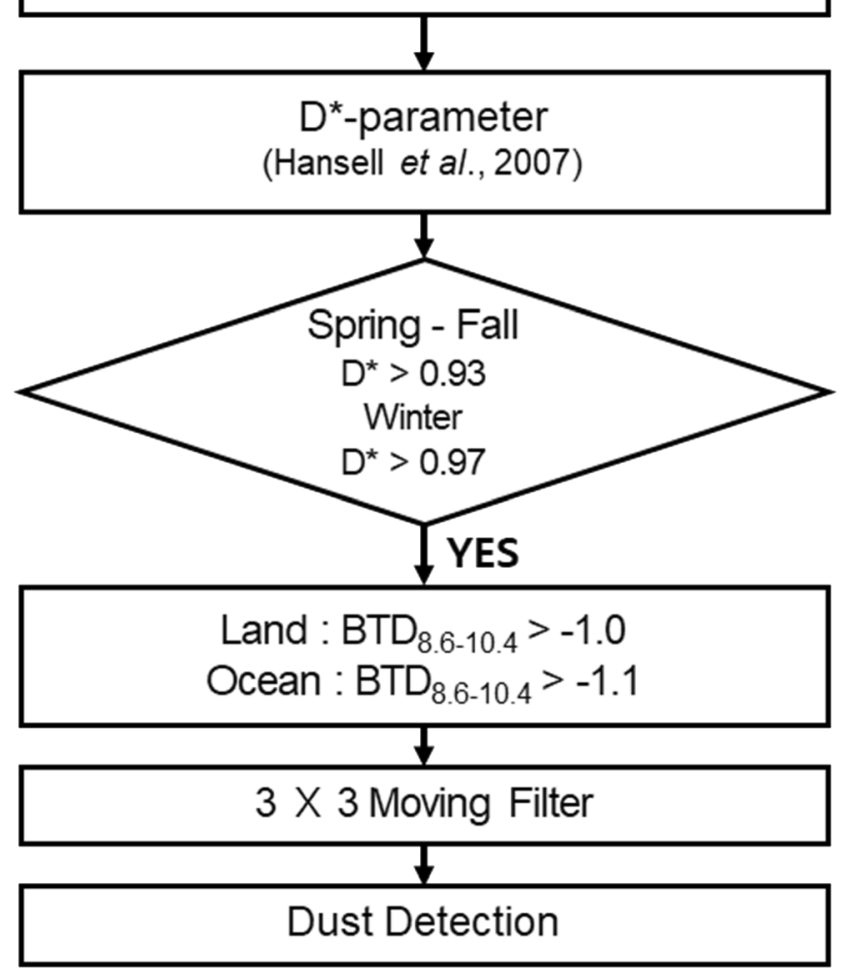

Fig. 1 Flowchart of the improved dust detection algorithm. The threshold values of $\mathrm{D}^{*}$ and $\mathrm{BTD}_{8.6-10.4}$ masking vary depending on the season and surface type, respectively

exist because $\mathrm{D*}$ is greatly affected by the sign of the numerator in eq. (2). $\mathrm{BTD}_{10.4-12.4}$ showed negative values over clear-sky desert due to effects of the emissivity and temperature of surface characteristics, and similar negative values were observed for fog over the ocean due to the attenuation by $\mathrm{TB}$. As a negative $\mathrm{BTD}_{10.4-12.4}$ indicates dust, in the above cases dust was not detected correctly. To overcome these problems, the following methods were introduced, using channels that can eliminate these effects.

\subsection{Masking}

\subsubsection{Clear-Sky Desert Surface}

$\mathrm{D}^{*}$ could detect the distribution and movement of dust during daytime over warm land surfaces, but false detection occurred over the desert due to the cold surface in the morning and night in spring and autumn. To eliminate the influence of land surface, which is sensitive to temperature, the characteristics of the $8.6 \mu \mathrm{m}$ and $11 \mu \mathrm{m}$ channels were used. The $8.6 \mu \mathrm{m}$ channel has a strong sensitivity towards the quartz and clay components that make up the dust. Thus, a higher absorption is observed in this channel compared to other infrared channels (Sokolik 2002), which further has a low emissivity on the desert surface under clear-sky conditions (De Paepe and Dewitte 2009). The larger the particle size, the smaller the emissivity of the $8.6 \mu \mathrm{m}$ channel, while that of the $11 \mu \mathrm{m}$ channel increases; the desert surface has high values at $11 \mu \mathrm{m}$ because the particles on the desert surface $(>75 \mu \mathrm{m}$ diameter) are larger than the dust particles $(<5 \mu \mathrm{m}$ diameter $)$ (Wald et al. 1998). Therefore, BTD $_{8.6-10.4}$ enables the differentiation of desert from dust. In this study, to obtain the threshold values of $\mathrm{BTD}_{8.6-10.4}$ for the discrimination, BTD analysis was performed using 12 representative cases, including dust and clear-sky desert conditions in 2017 and 2018. Figure 2 shows a scatter diagram of $\mathrm{BTD}_{8.6-10.4}$ and $\mathrm{BTD}_{10.4-12.4}$ for the areas of the selected $1^{\circ} \times 1^{\circ}$ latitude and longitude ranges for the dust and desert detection. Based on this analysis, the threshold of $\mathrm{BTD}_{8.6-10.4}$ for dust discrimination was set to $-1 \mathrm{~K}$. The BTD analysis demonstrated that $\mathrm{BTD}_{10.4-12.4}$ of the two targets had similar ranges, while the desert surface for clear-sky cases (blue dots) had less than $-1 \mathrm{~K}$ negative BTD $_{8.6-10.4}$ values, and dust cases (red dots) had values above the criterion. Thus, areas with higher values than this threshold value were considered as dust areas $\left(\mathrm{BTD}_{8.6-10.4}>-1 \mathrm{~K}\right)$, and false signals caused by land surface effects over the desert were eliminated.

\subsubsection{Fog}

D* applied to Himawari-8 incorrectly detects fog as dust over the oceans surrounding the Korean Peninsula. In this study, $\mathrm{BTD}_{8.6-10.4}$ analysis was performed by selecting $1^{\circ} \times 1^{\circ}$ latitude and longitude ranges using 19 cases, including fog and dust events that occurred in 2017 and 2018 to obtain the $\mathrm{BTD}_{8.6-10.4}$ threshold value for fog and dust. These false fog signals are also caused by $\mathrm{BTD}_{10.4-12.4}$, which is affected by water vapor over ocean. Dust over the ocean is influenced by the $12 \mu \mathrm{m}$ channel, which is more sensitive to water vapor than the $11 \mu \mathrm{m}$ channel (Hong et al. 2010). In the $12 \mu \mathrm{m}$ channel, absorption increases, which results in values similar to that of fog in the atmospheric low layer. To solve this problem, the $8.6 \mu \mathrm{m}$ channel, which has the largest absorption for water vapor, was used. As the amount of water vapor in the atmosphere increases, more water vapor is absorbed at $8.6 \mu \mathrm{m}$ than at $11 \mu \mathrm{m}$ and $12 \mu \mathrm{m}$, and the value of $\mathrm{BTD}_{8.6-10.4}$ becomes strongly negative (Strabala et al. 1994). As the emissivity shows little change for each infrared wavelength over the ocean surface, where the water vapor content is higher, the $8.6 \mu \mathrm{m}$ channel, which features a relatively large absorption attributable to water vapor in the lower layer, can be effectively used for retrieving water vapor information. In this manner, fog, which are water clouds in the lower atmosphere, can be separated from dust. Figure 3 shows the $\mathrm{BTD}_{10.4-12.4}$ and corresponding $\mathrm{BTD}_{8.6-10.4}$ values for fog and dust cases. BTD $_{10.4-12.4}$ for fog and dust over the ocean showed a similar 
Fig. 2 Scatter plot of $\mathrm{BTD}_{10.4}$ ${ }_{12.4}$ and $\mathrm{BTD}_{8.6-10.4}$ for clear-sky desert (blue) pixels and dust (red) pixels over land, covering about 12 cases in 2017 and 2018

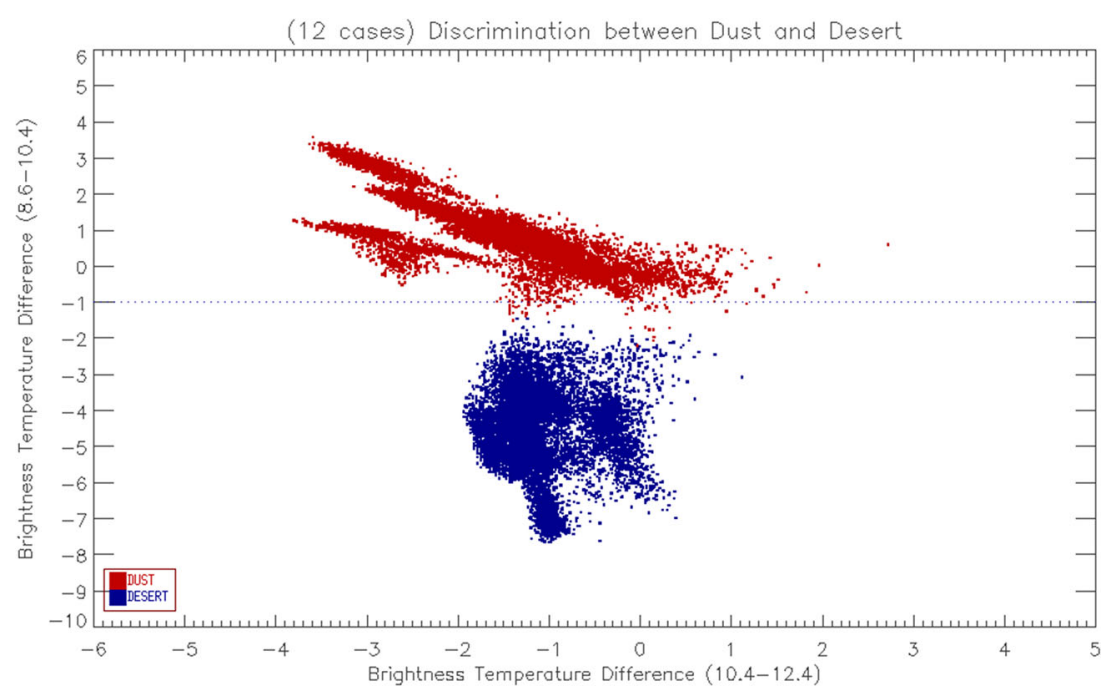

range, whereas $\mathrm{BTD}_{8.6-10.4}$ showed a difference of $-1.1 \mathrm{~K}$. Based on this value, pixels with higher values than $-1.1 \mathrm{~K}$ were regarded as dust $\left(\mathrm{BTD}_{8.6-10.4}>-1.1 \mathrm{~K}\right)$, and false signals of the fog region with lower values were removed.

\section{Results}

A case study based on correlation analyses with AERONET data was performed for the improved $\mathrm{D}^{*}$ by applying the masking method based on $\mathrm{BTD}_{8.6-10.4}$. The figures in this section show the results of the verification of $\mathrm{D}^{*}$ using qualitative and quantitative methods. The case studies were conducted on 3 daytime cases in spring and 1 nighttime case in winter, and qualitative verification was carried out using the Himawari-8 true color RGB, GOCI true color RGB, and COMS AI during the day and the Himawari-8 dust RGB, $\mathrm{PM}_{10}$ concentration map, and COMS AI at night. For quantitative analyses, the correlation with the AERONET AOD, which is related to the amount of aerosols in the vertical atmosphere, and the Himawari-8 D* for the 2017 and 2018 dust cases was analyzed.

\subsection{Case Study}

\subsubsection{Dust over Source Region at Daytime}

On the morning of May 3, 2017, dust originated from the Gobi Desert, as low pressure developed near Lake Baikal, and it was observed to move east along the back of the low pressure system. Figure 4 shows the dust over the Gobi Desert on May 3, 06 UTC detected by the improved $D^{*}$ and the Himawari- 8 true color RGB and COMS AI images, which were used to evaluate $\mathrm{D}^{*}$ qualitatively. In the true color RGB image, yellowish brown dust appeared over wide areas in the Gobi Desert and Inner Mongolia region. The $\mathrm{D}^{*}$ output using the improved algorithm detected the same area, having high values of more than 1.2. The AI image observed by COMS also detected identical dust
Fig. 3 Scatter plot of $\mathrm{BTD}_{10.4}$ 12.4 and $\mathrm{BTD}_{8.6-10.4}$ for fog (green) pixels and dust (orange) pixels over the ocean, covering about 19 cases in 2017 and 2018

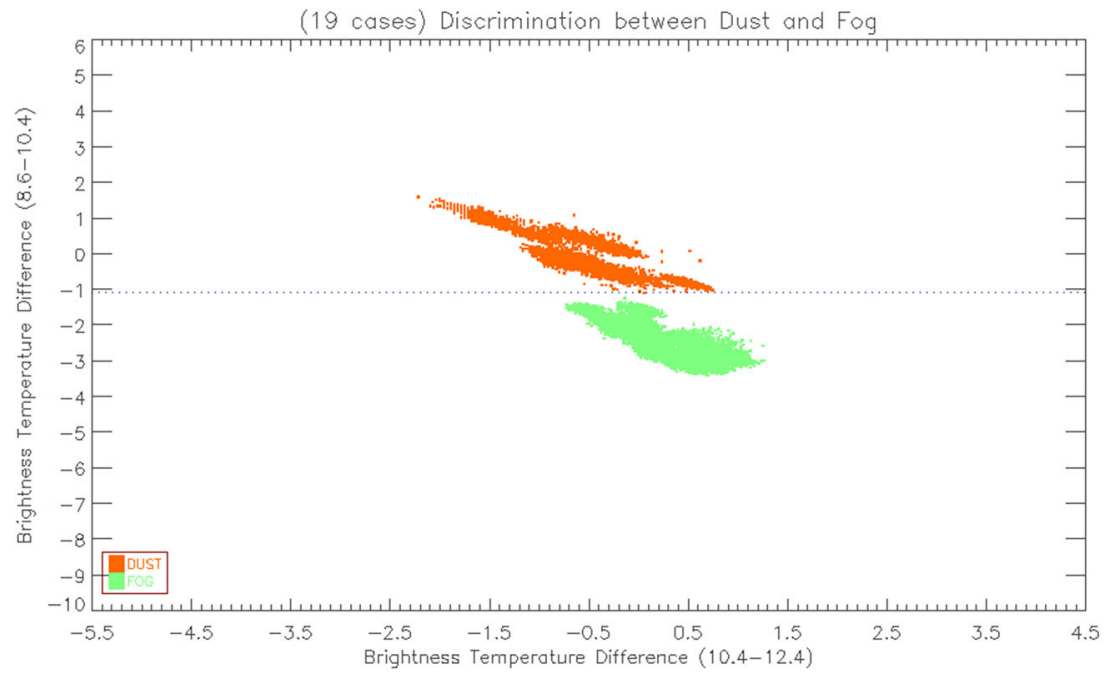




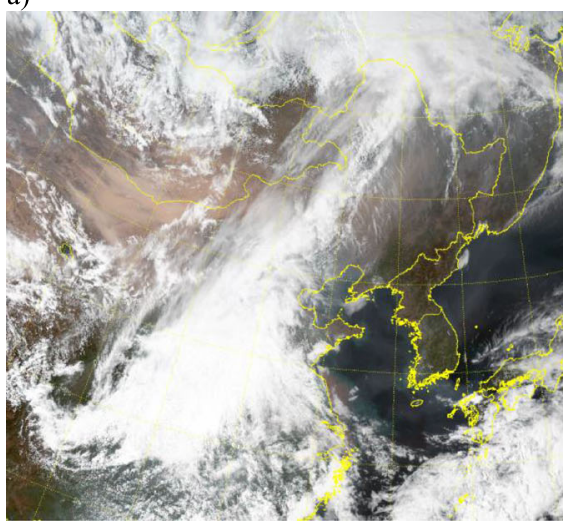

b)

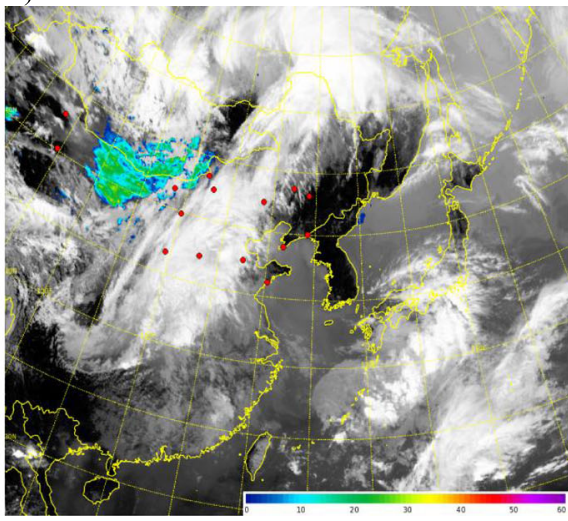

c)

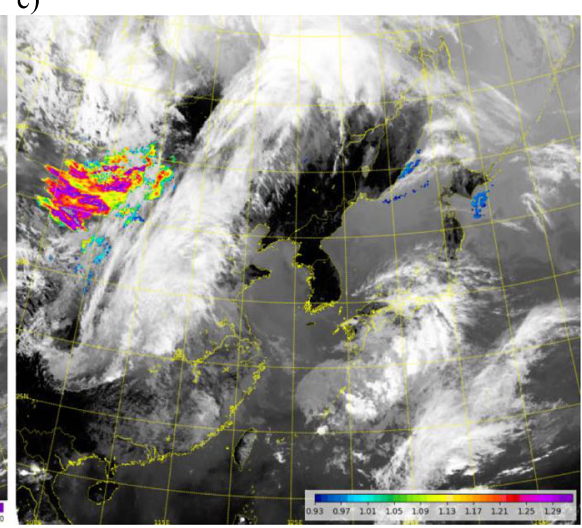

Fig. 4 a Himawari-8 true color RGB image, b COMS Aerosol Index, and c improved Himawari-8 D* for airborne dust over the Gobi desert at 06 UTC on May 3, 2017

areas in the RGB images and showed high values, with an index of approximately 10-30.

\subsubsection{Dust Over the Ocean at Daytime}

The low-pressure system passed through Mongolia and northeast China on March 26, 2018, and the back of the system led to an extensive outbreak of dust. The dust storm followed the northeastern air current at the back of the lowpressure system, but it passed the West Sea and central Korean Peninsula, remaining suspended air by an anticyclone located south of the Korean Peninsula. Figure 5 shows comparison images of the improved $\mathrm{D}^{*}$, the COMS GOCI true color RGB, and the COMS AI for the dust passing the West Sea and the central Korean Peninsula at 04 UTC on March 29. In the true color RGB, banded and yellowish dust appeared clearly from the Bohai Bay to the East Sea, and a wide area of fog was observed over the West Sea. The dust floating on the upper layer was well detected in the improved $D^{*}$ output, while the AI using two channels $(11 \mu \mathrm{m}$ and $12 \mu \mathrm{m})$ incorrectly detected fog as dust. For the dust area, AI and $\mathrm{D}^{*}$ were found to be in the range of about 5-20 and about 0.97-1.2, respectively.

\subsubsection{Dust over the Ocean and Land at Daytime}

On April 13, 2018, dust originated from the rear of the low-pressure system centered in eastern Mongolia and moved southeast. The dust, which was dropped by a migratory anticyclone at the back side of the trough, remained suspended for many hours and affected the Korean Peninsula up to the 16 th. Figure 6 shows a comparison of $\mathrm{D}^{*}$, the GOCI true color RGB image, and the AI for the dust detection from Shandong Peninsula to the Korean Peninsula at 01 UTC on April 15. In the GOCI true color RGB image, murky and gray-brown dust appeared in the West Sea and the Korean Peninsula. $\mathrm{D}^{*}$ detected dust floating over the West Sea, whereas AI showed that dust signals disappeared in the area. The $\mathrm{D}^{*}$ values over the West Sea were low, in the range of approximately $0.93-1.02$. In this case, there was a difference in detection between the COMS AI and $\mathrm{D}^{*}$, with thin dust plumes on the ocean having a positive BTD11-12 value due to the effects of water vapor and specific heat differences for this surface type. The dust signal decreased in the COMS AI due to the BTV, which was used to correct the error caused by water vapor and the false signal by surface characteristics, while the BTD11-12 in D* was reflected without attenuation effects.

\subsubsection{Dust over Land at Nighttime}

On December 1, 2018, the dust that originated from the Gobi Desert and the Chinese Loess Plateau by strong winds at the rear of the low-pressure system passing through eastern Mongolia weakened the movement along the edge of the extended high pressure area in northern China. Figure 7 shows a comparison of the improved D*, AI, Himawari-8 dust RGB image, and $\mathrm{PM}_{10}$ concentration chart, which were acquired for dust moving along the edge of the high-pressure system over central and northeastern China at 19 UTC on December 2. In the Himawari-8 dust RGB image, a long and reddish dust area was detected across central and northeastern China. High $\mathrm{PM}_{10}$ concentrations exceeding $500 \mu / \mathrm{m}^{3}$ were observed in Yan'an, which is included in the reddish area of the dust RGB image, and a concentration of approximately $200 \mu \mathrm{m} / \mathrm{m}^{3}$ was observed in Wulatezhongqi and Dongsheng in Inner Mongolia. D* detected a dust area with values of about 1.0-1.5, corresponding to the red area in the dust RGB image, but the AI could not detect any such area. The 
a)

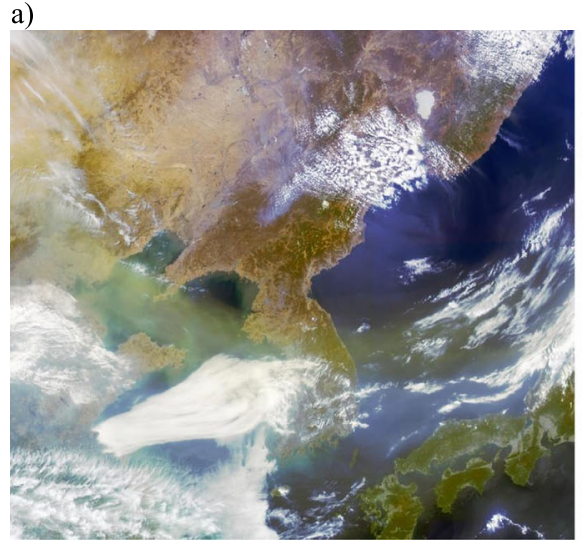

b)

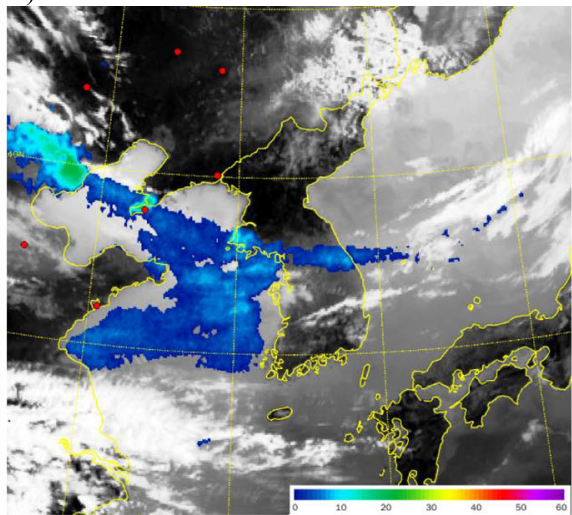

c)

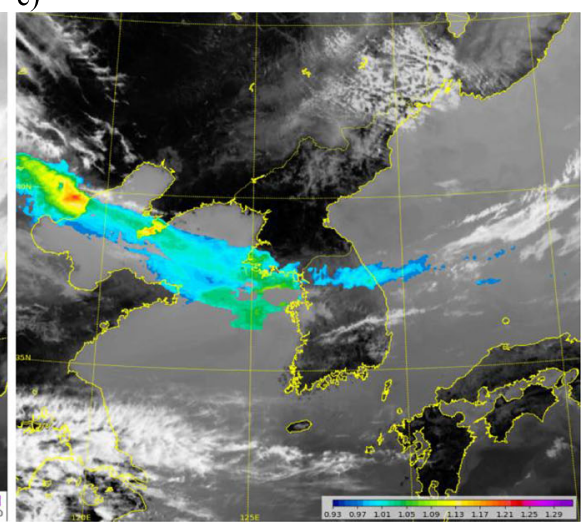

Fig. 5 a COMS GOCI true color RGB image, b COMS Aerosol Index, and $\mathbf{c}$ improved Himawari-8 D* for airborne dust flown over the Bohai Sea and Yellow Sea at 04 UTC on March 29, 2018

reason for the missing area in the $\mathrm{AI}$ image is interpreted as dust signals being attenuated due to small differences in the $\mathrm{BTD}_{11-12}$ values, which are affected by the surface temperature between the land surface and dust.

\subsection{Correlation Analysis with AERONET AOD}

To verify the improved dust detection method, a correlation analysis was performed with the AERONET AOD, which has a high accuracy. For this purpose, the AOD data observed at 28 AERONET sites in East Asia and D* products of 1775 cases retrieved for dust cases during the period of 2017-2018 were used. The two variables showed a positive correlation of 0.604 (Rs). In addition, as the AOD value increased, the $\mathrm{D}^{*}$ value also tended to increase exponentially (Fig. 8). Hansell et al. (2007) reported that $D^{*}$ increased exponentially as the optical depth $(\tau)$ increased. The verification performed in this study shows meaningful results in that a similar pattern appears when using actual satellite data.

\section{Summary and Discussion}

This study focused on developing a dust detection method to support dust monitoring in real time. As infrared channels of geostationary satellites are useful for continuous day and night monitoring, we applied the Himawari-8 geostationary satellite data to the $\mathrm{D}^{*}$ method, which uses three infrared channels, and optimized it for East Asia. D* can discriminate dust from dust mixed with cirrus clouds by adding the $8.6 \mu \mathrm{m}$ channel, instead of using the single BTD $_{10.4-12.3}$. Although three infrared channels were used, as the existing $D^{*}$ method is greatly affected by the numerator of $\mathrm{BTD}_{11-12}$, dust was incorrectly detected over the desert under clear-sky conditions due to the differences in the temperature and emissivity of different surfaces, and fog generated above the ocean due to the effect of water vapor. To reduce the occurrence of such false detection, the effects of surface temperature in the desert and water vapor above the ocean were eliminated through the analysis of $\mathrm{BTD}_{8.6-11}$, based on the characteristics of the $8.6 \mu \mathrm{m}$ channel. This channel is related to the spectral refractive index a)

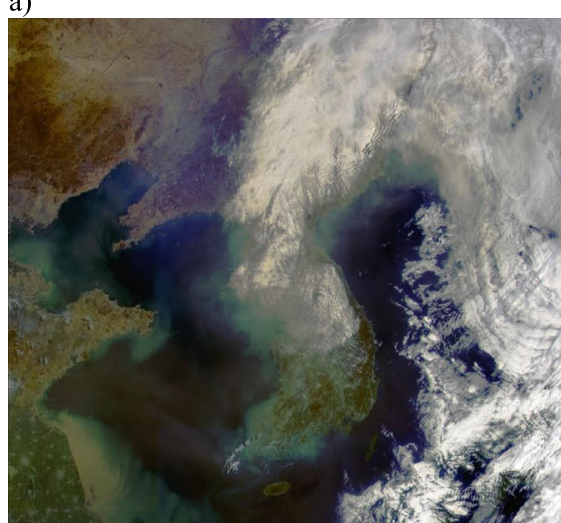

b)

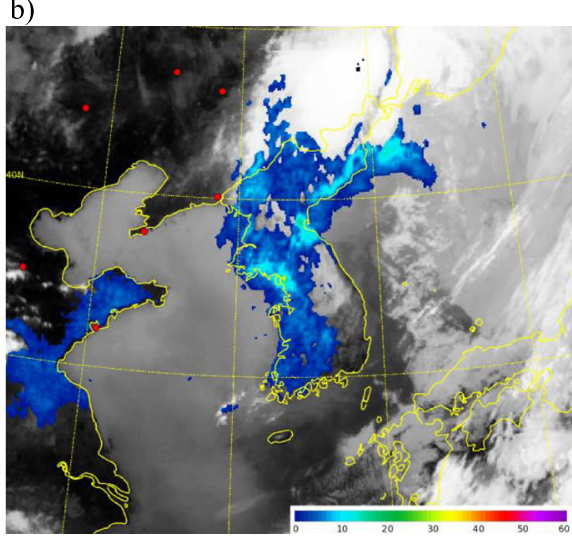

c)

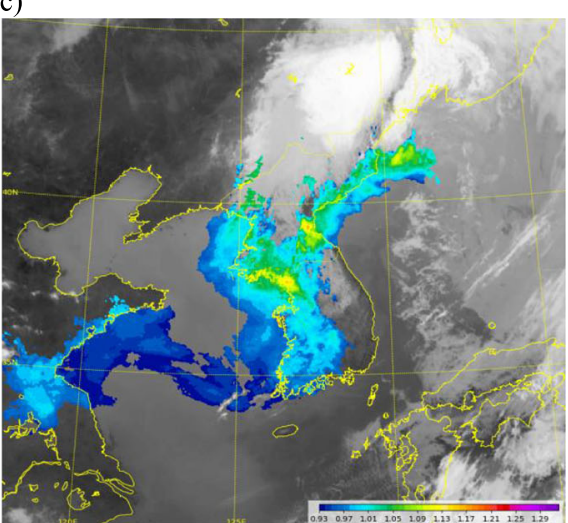

Fig. 6 a COMS GOCI true color RGB image, b COMS Aerosol Index, and c improved Himawari-8 D* for airborne dust over the Shandong Peninsula, Yellow Sea, and the Korean Peninsula at 01 UTC on 15 April, 2018 
a)

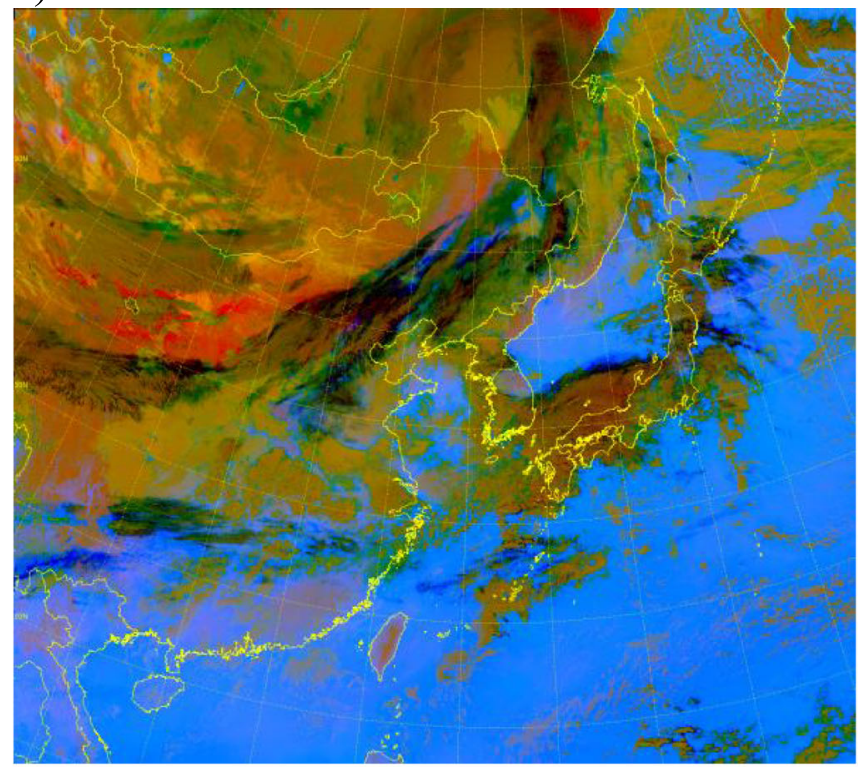

c)

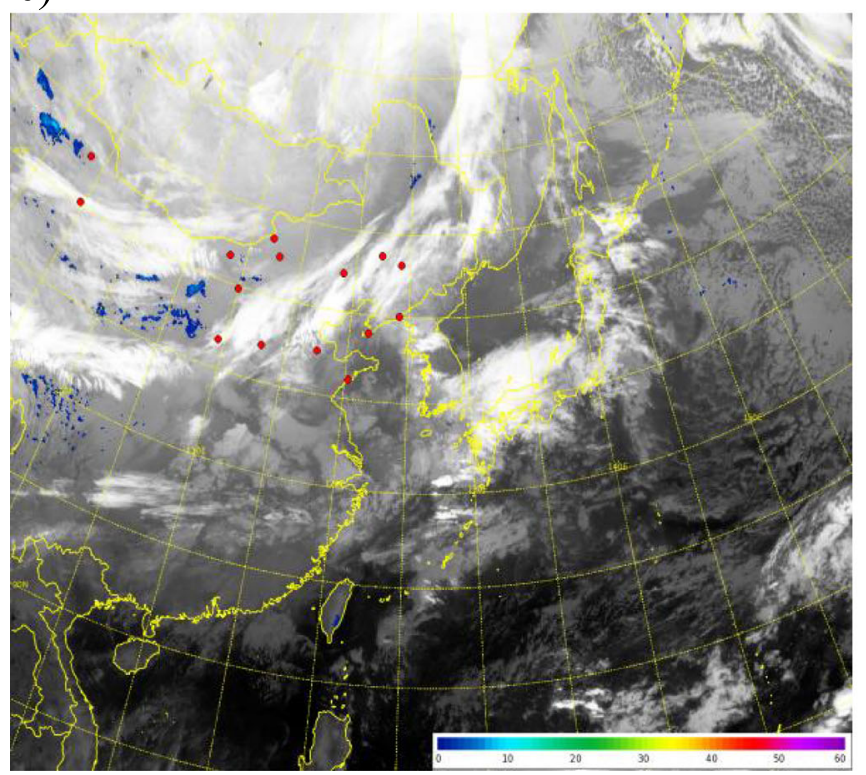

b)

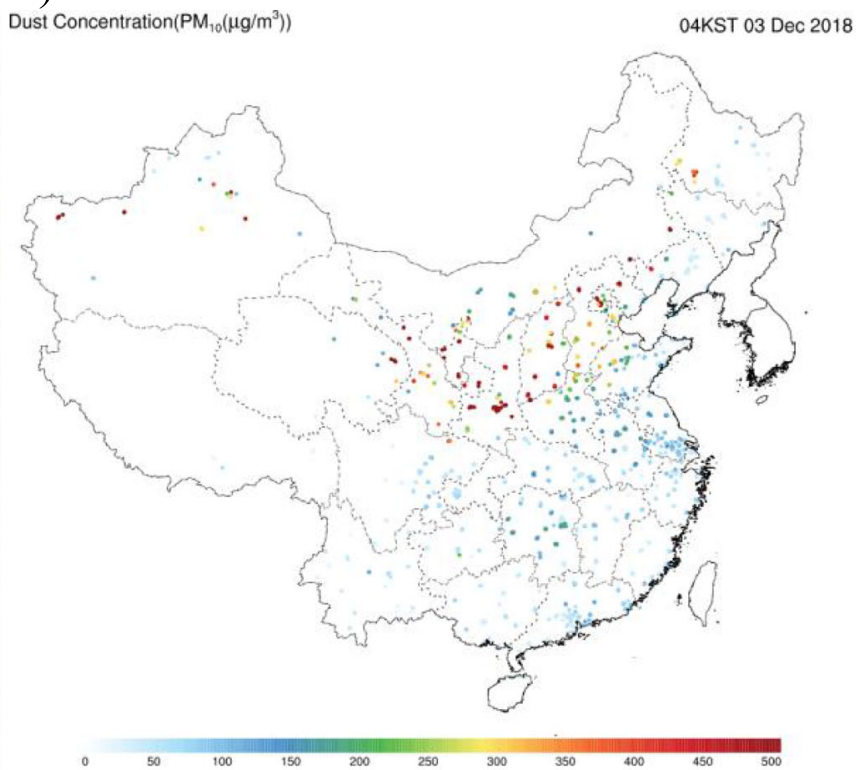

d)

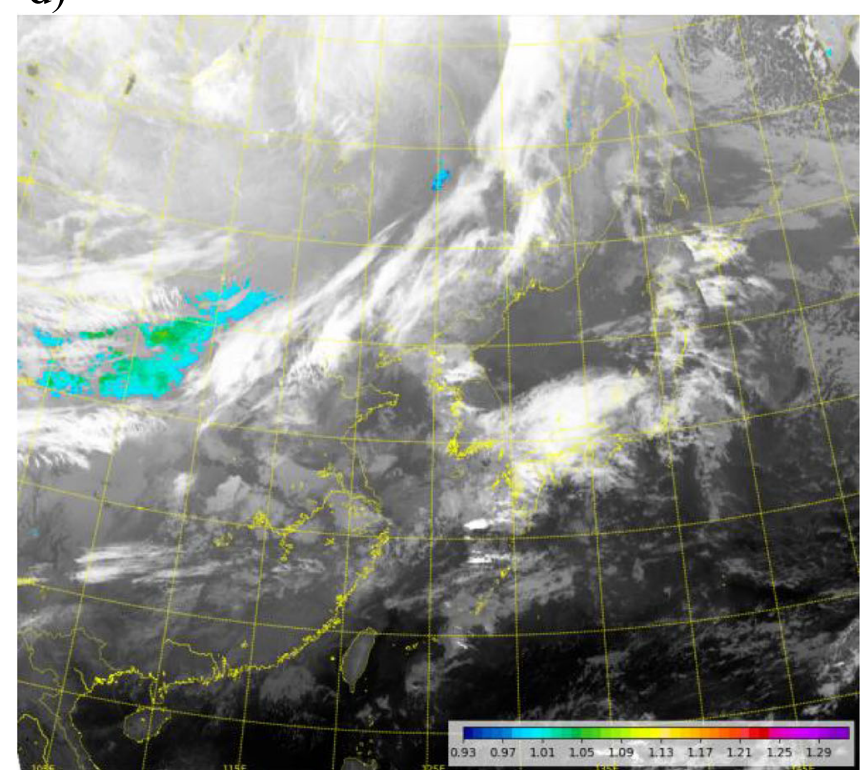

Fig. 7 a Himawari-8 Dust RGB image, b PM $_{10}$ concentration chart for China, c COMS Aerosol Index, and d improved Himawari-8 D* for airborne dust over Northern China at 19 UTC on December 2, 2018

and particle size of minerals and has the highest water absorption as compared to other infrared channels. Masks for clear-sky desert and fog above the ocean were classified based on the threshold values obtained from the $\mathrm{BTD}_{8.6-11}$ analysis for these weather phenomena in various cases. Through a qualitative evaluation using RGB composite images and ground observation data, the improved dust detection method was verified to be capable of distinguishing desert and dust on land, fog from dust on the ocean as well as detecting dust at night in early winter. Correlating the improved D* with the AERONET AOD in the dust cases that occurred in 2017 and 2018, including the cases used for qualitative evaluation, the two variables showed a significant correlation of approximately 0.604 . In addition, the improved $\mathrm{D}^{*}$ appeared to increase exponentially with an increasing AOD.

However, the improved D* still contains the characteristics of $\mathrm{BTD}_{11-12}$, which is sensitive to the surface effects and column water vapor. Therefore, there are limitations in that dust is excessively detected on land and in high latitude regions when the temperature is low in winter, while dust is only weakly detected over the ocean. In this study, threshold values for classifying dust by $\mathrm{D}^{*}$ and $\mathrm{BTD}_{8.6-11}$ were determined based on a limited number of cases. As 


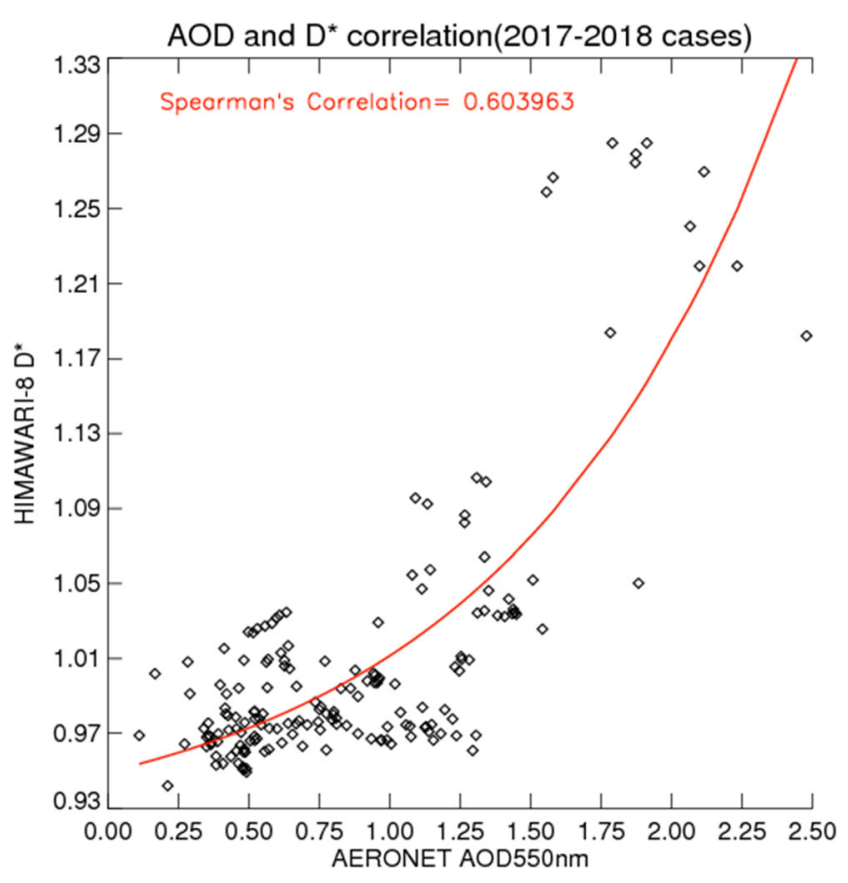

Fig. 8 Relationship between Himawari-8 D* and AERONET AOD. With an increasing AOD, D* increased exponentially. The correlation coefficient (Rs) between the two variables is 0.604

the radiation of the infrared channels is variable depending on the altitude and particle size of the dust, surface type, temperature, and the amount of water vapor, it is necessary to use detailed threshold values according to season, time, and surface type by considering more cases. Furthermore, analyses using various datasets, such as Lidar, CALIPSO, and weather charts, should be performed in the future to understand the pattern of changes in the distribution, movement, and intensity of dust according to changes in dust characteristics, such as altitude and surface temperature. The next-generation geostationary GEO-KOMPSAT$2 \mathrm{~A}(\mathrm{GK}-2 \mathrm{~A})$ satellite, with a multi-channel radiometer similar to Himawari-8, will probably provide better observations for the East Asian region. The proposed dust detection method will be applied to the GK-2A satellite data, which is expected to help in daily monitoring.

Acknowledgements This research was supported by the "Development of Satellite Data Utilization and Operation Supportive Technology" initiative of the NMSC (National Meteorological Satellite Center) of the KMA (Korea Meteorological Administration).

Open Access This article is licensed under a Creative Commons Attribution 4.0 International License, which permits use, sharing, adaptation, distribution and reproduction in any medium or format, as long as you give appropriate credit to the original author(s) and the source, provide a link to the Creative Commons licence, and indicate if changes were made. The images or other third party material in this article are included in the article's Creative Commons licence, unless indicated otherwise in a credit line to the material. If material is not included in the article's Creative Commons licence and your intended use is not permitted by statutory regulation or exceeds the permitted use, you will need to obtain permission directly from the copyright holder. To view a copy of this licence, visit http://creativecommons.org/licenses/by/4.0/.

\section{References}

Ackerman, S.A.: Remote sensing aerosols using satellite infrared observations. J. Geophys. Res. 102, 17069-17079 (1997)

Cesnulyte, V., Lindfors, A.V., Pitkanen, M.R.A., Lehtinen, K.E.J., Morcrette, J.-J., Arola, A.: Comparing ECMWF AOD with AERONET observations at visible and UV wavelengths. Atmos. Chem. Phys. Discuss. 13, 19853-19893 (2013). https://doi.org/10. 5194/acpd-13-19853-2013

Correia, A., Pires, C.: Validation of aerosol optical depth retrievals by remote sensing over Brazil and South America using MODIS. Anais do XIV Congresso Brasileiro de Meteorologia (2006)

De Paepe, B., Dewitte, S.: Dust aerosol optical depth retrieval over a desert surface using the SEVIRI window channels. J. Atmos. Ocean. Technol. 26, 704-718 (2009). https://doi.org/10.1175/ 2008JTECHA1109.1

Eck, T.F., Holben, B.N., Reid, J.S., Dubovik, O., Smirnov, A., O’Neill, N.T., Slutsker, I., Kinne, S.: Wavelength dependence of the optical depth of biomass burning, urban, and desert dust aerosols. J. Geophys. Res. 104, 31333-31349 (1999)

El-Askary, H., Park, S.K., Ahn, M.H., Prasad, A., Kafatos, M.: On the detection and monitoring of the transport of an Asian dust storm using multi-sensor satellite remote sensing. J. Environ. Inform. 25, 99-116 (2015). https://doi.org/10.3808/jei.201500306

Giles, D.M., Sinyuk, A., Sorokin, M.G., Schafer, J.S., Smirnov, A., Slutsker, I., Eck, T.F., Holen, B.N., Lewis, J.R., Campbell, J.R., Welton, E.J., Korkin, S.V., Lyapustin, A.I.: Advancements in the aerosol robotic network (AERONET) version 3 database-automated near-real-time quality control algorithm with improved cloud screening for sun photometer aerosol optical depth (AOD) measurements. Atmos. Meas. Tech. 12, 169-209 (2019)

$\mathrm{Gu}$, Y., Rose, W.I., Bluth, G.J.S.: Retrieval of mass and sizes of particles in sandstorms using two MODIS IR bands: a case study of April 7, 2001 sandstorm in China. Geophys. Res. Lett. 30(15), 1805 (2003). https://doi.org/10.1029/2003GL017405

Guo, J., Lou, M., Miao, Y., Wang, Y., Zeng, Z., Liu, H., He, J., Xu, H., Wang, F., Min, M., Zhai, P.: Trans-Pacific transport of dust aerosols from East Asia: insights gained from multiple observations and modeling. Environ. Pollut. 230, 1030-1039 (2017)

Ha, J.-S., Kim, J.-H., Lee, H.-J.: Sensitivity analysis of IR aerosol detection algorithm. Korean J. Remote Sens. 22, 507-518 (2006) (in Korean with English abstract)

Hansell, R.A., Ou, S.C., Liou, K.N., Roskovensky, J.K., Tsay, S.C., Hsu, C., Ji, Q.: Simultaneous detection/separation of mineral dust and cirrus clouds using MODIS thermal infrared window data. Geophys. Res. Lett. 34, L11808 (2007). https://doi.org/10.1029/ 2007GL029388

Hashimoto, T., Ohkawara, N.: Development of "Kosa monitoring product" from infrared data of the geostationary meteorological satellite (MTSAT-1R). Meteorological Satellite Center Technical Note. 49, 1-17 (2007) (in Japanese with English abstract)

Haywood, J., Boucher, O.: Estimates of the direct and indirect radiative forcing due to tropospheric aerosols: a review. Rev. Geophys. 38, 513-543 (2000). https://doi.org/10.1029/1999RG000078

Holben, B.N., Eck, T.F., Slutsker, I., Tanre, D., Buis, J.P., Setzer, A., Vermote, E., Reagan, J.A., Kaufman, Y.J., Nakajima, T., Lavenu, F., Jankowiak, I., Smirnov, A.: AERONET- a federated instrument network and data archive for aerosol characterization. Remote Sens. Environ. 66, 1-16 (1998). https://doi.org/10.1016/S0034-4257(98) 00031-5 
Hong, S.J., Kim, J.H., Ha, J.S.: Possibility of applying infrared background threshold values for detecting Asian dust in spring from geostationary satellite. Korean J. Remote Sens. 26, 387-394 (2010) (in Korean with English abstract)

Kim, M.-J., Kim, Y.J., Sohn, E.-H., Kim, K.-L., Ahn, M.-H.: The study on the quantitative dust index using geostationary satellite. Atmos. Res. 18, 267-277 (2008) (in Korean with English abstract)

Legrand, M., Bertrand, J.J., Desbois, M., Menenger, L., Fouquart, Y.: The potential of infrared satellite data for the retrieval of Saharan dust optical depth over Africa. J. Appl. Meteorol. 28, 309-319 (1989)

Legrand, M., Plana-Fattori, A., N'doumé, C.: Satellite detection of dust using the IR imagery of Meteosat 1. Infrared difference dust index. J. Geophys. Res. 106(D16), 18251-18274 (2001). https://doi.org/10. 1029/2000JD900749

Liu, Y., Liu, R., Cheng, X.: Dust detection over desert surfaces with thermal infrared bands using dynamic reference brightness temperature differences. J. Geophys. Res. Atmos. 118, 8566-8584 (2013). https://doi.org/10.1002/jgrd.50647

NIMS (National Institute of Meteorological Sciences), 2019: Dust Report in 2018 (in Korean)

Prata, A.J.: Observations of volcanic ash clouds in the $10-12 \mu \mathrm{m}$ window using AVHRR/2 data. Int. J. Remote Sens. 10, 751-761 (1989). https://doi.org/10.1018/01431168908903916

Remer, L.A., Kaufman, Y.J., Tanre, D., Mattoo, S., Chu, D.A., Martins, J.V., Li, R.-R., Ichoku, C., Levy, R.C., Kleidman, R.G., Eck, T.F., Vermote, E., Holben, B.N.: The MODIS aerosol algorithm, products, and validation. J. Atmos. Sci. 62, 947-973 (2005). https://doi. org/10.1175/JAS3385.1

Schepanski, K., Tegen, I., Laurent, B., Heinold, B., Macke, A.: A new Saharan dust source activation frequency map derived from MSGSEVIRI IR-channels. Geophys. Res. Lett. 34, L18803 (2007). https://doi.org/10.1029/2007GL030168

Schneider, D.J., Rose, W.I., Kelley, L.: Tracking of 1992 eruption clouds from crater peak vent of mount Spurr volcano, Alaska, using AVHRR. U.S. Geol. Surv. Bull. 2139, 27-36 (1995)

Shenk, W.E., Curran, R.J.: The detection of dust storms over land and water with satellite visible and infrared measurements. Mon. Weather Rev. 102, 830-837 (1974). https://doi.org/10.1175/15200493(1974)102<0830:TDODSO >2.0.CO;2
Smirnov, A., Holben, B.N., Eck, T.F., Dubovik, O., Slutsker, I.: Cloudscreening and quality control algorithms for the AERONET database. Remote Sens. Environ. 73, 337-349 (2000). https://doi.org/10. 1016/S0034-4257(00)00109-7

Sokolik, I.N.: The spectral radiative signature of wind-blown mineral dust: implications for remote sensing in the thermal IR region. Geophys. Res. Lett. 29, 2154-27-4 (2002). https://doi.org/10. 1029/2002GL015910

Sokolik, I.N., Toon, O.B.: Incorporation of mineralogical composition into models of the radiative properties of mineral aerosol from UV to IR wavelengths. J. Geophys. Res. 104, 9423-9444 (1999). https:// doi.org/10.1029/1998JD200048

Strabala, K.I., Ackerman, S.A., Menzel, W.P.: Cloud properties inferred

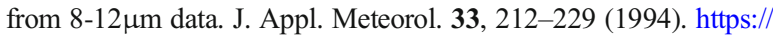
doi.org/10.1175/1520-0450(1994)033<0212:CPIFD>2.0.CO;2

Tang, B., Li, Z.-L.: Estimation of instantaneous net surface longwave radiation from MODIS cloud-free data. Remote Sens. Environ. 112, 3482-3492 (2008). https://doi.org/10.1016/j.rse.2008.04.004

Vickers, R.S., Lyon, R.J.P.: Infrared sensing from spacecraft: a geological interpretation. Thermophysics of Spacecraft and Planetary Bodies. 20, 585-607 (1967)

Wald, A.E., Kaufman, Y.J., Tanre, D., Gao, B.-C.: Daytime and nighttime detection of mineral dust over desert using infrared spectral contrast. J. Geophy. Res. 103, 32307-32313 (1998). https://doi. org/10.1029/98JD01454

Wurzler, S., Reisin, T.G., Levin, Z.: Modification of mineral dust particles by cloud processing and subsequent effects on drop size distributions. J. Geophys. Res. 105, 4501-4512 (2000). https://doi.org/ 10.1029/1999JD900980

Yamanouchi, T., Suzuki, K., Kawaguchi, S.: Detection of clouds in Antarctica from infrared multispectral data of AVHRR. J. Meteor. Soc. Japan. 65, 949-961 (1987). https://doi.org/10.2151/jmsj1965. 65.6 949

Zhang, P., Lu, N.M., Hu, X.Q., Dong, C.H.: Identification and physical retrieval of dust storm using three MODIS thermal IR channels. Glob. Planet. Chang. 52, 197-206 (2006). https://doi.org/10.1016/ j.gloplacha.2006.02.014

Publisher's Note Springer Nature remains neutral with regard to jurisdictional claims in published maps and institutional affiliations. 